\title{
TERLEPASNYA JANGKAR KIRI PADA SAAT BERLABUH JANGKAR DI ANCHORAGE AREA PELABUHAN TANJUNG INTAN CILACAP
}

\author{
Priyangga Aji Nugroho ${ }^{a}$, Moh. Aziz Rohman ${ }^{b}$ dan Nur Rohmah \\ ${ }^{a}$ Taruna Program Studi Nautika PIP Semarang \\ ${ }^{b}$ Dosen Program Studi Nautika PIP Semarang \\ ${ }^{\mathrm{c}}$ Dosen Program Studi KALK PIP Semarang
}

\begin{abstract}
ABSTRAK
Jangkar kiri MV. DK 01 terlepas pada saat berlabuh jangkar di anchorage area Pelabuhan Tanjung Intan Cilacap sehingga perlu diketahui faktor-faktor yang menyebabkan terlepasnya jangkar kiri pada saat berlabuh jangkar dan upaya yang perlu dilakukan setelah terlepasnya jangkar kiri pada saat open brake tersebut agar proses berlabuh jangkar dapat dilaksanakan dengan baik.

Metode yang digunakan adalah fishbone analysis untuk mencari faktor-faktor permasalahan dan USG analysis untuk menghasilkan perioritas masalah. Faktor-faktor penyebab yaitu kurangnya kesadaran crew kapal akan pentingnya proses berlabuh jangkar, pemilihan metode berlabuh jangkar yang kurang efektif, kurangnya perawatan dan pengecekan windlass, kondisi lingkungan yang tidak mendukung.

Upaya yang perlu dilakukan adalah Second Officer langsung memplotting posisi jangkar kiri yang terjatuh untuk menghindari jangkar kiri tersebut hilang dan Nahkoda sebagai pemimpin kapal langsung mengambil kebijakan untuk menggunakan jangkar kanan dengan metode walk back ship anchoring method dimana jangkar kanan diturunkan dengan hati-hati menggunakan rem untuk menghindari kejadian yang sama.
\end{abstract}

Kata kunci: analisis, jangkar, open brake

\section{PENDAHULUAN}

MV. DK 01 merupakan salah satu jenis kapal curah (bulk carrier) yang mengangkut muatan batu bara dengan route pelayaran tetap (liner) dari Pulau Kalimantan menuju Pelabuhan Tanjung Intan, Cilacap. Muatan curah merupakan muatan yang dimuat tanpa menggunakan kemasan atau pembungkus. Batu bara itu sendiri merupakan salah satu jenis muatan curah yang termasuk ke dalam golongan muatan berbahaya sehingga membutuhkan penanganan dan pengaturan khusus.

Pada saat akan masuk wilayah Pelabuhan Tanjung Intan, Cilacap, MV. DK 01 kadang-kadang harus berlabuh jangkar terlebih dahulu sebelum sandar. Berlabuh jangkar merupakan suatu keadaan saat kapal terapung tanpa berolah gerak terhadap air. Berlabuh jangkar dilakukan di daerah tertentu pada setiap pelabuhan atau di luar daerah pelabuhan, dengan memperhitungkan kedalaman air laut dan keadaan sekitar. Berlabuh jangkar dilaksanakan pada saat menunggu waktu masuk ke pelabuhan, menunggu penyelesaian berkas untuk masuk atau keluar suatu pelabuhan, untuk menghindari penumpukan kapal di dalam pelabuhan, dan dapat juga karena kapal sedang mengalami perbaikan di atas permukaan air. Menurut Agus Hadi Purwantomo (2018:75), berlabuh jangkar adalah mengikat kapal pada dasar perairan agar kapal tidak hanyut karena arus atau angin untuk melaksanakan suatu kegiatan, seperti: menunggu clearance memasuki pelabuhan, menunggu pandu, maupun menunggu dermaga yang kosong agar dapat melaksanakan proses bongkar. Sering terjadi keadaan arus yang kuat maupun hujan lebat membuat proses 
sandar tersebut menjadi tertunda, sehingga membuat kapal harus berlabuh jangkar terlebih dahulu.

Mualim sebagai top management keselamatan dan keamanan kapal dituntut harus menguasai setiap keadaan saat kapal sandar, berlabuh jangkar maupun ketika sedang berlayar. Selain kemampuan yang harus dimiliki oleh seorang Mualim dalam mengetahui setiap keadaan pada saat kapal sedang berlabuh jangkar, perawatan serta kelengkapan anchor (jangkar) juga menjadi faktor penting yang sangat menunjang keselamatan dan keamanan kapal.

Keadaan darurat yang terjadi pada saat kapal sedang berlabuh jangkar pun bermacam-macam, seperti tubrukan, kandas, maupun jangkar larat. Menurut Agus Hadi Purwantomo (2018:3), tubrukan yaitu suatu keadaan darurat yang disebabkan karena terjadinya tubrukan kapal dengan kapal, kapal dengan dermaga, maupun kapal dengan benda terapung lainnya yang dapat membahayakan keselamatan jiwa manusia, harta benda di atas kapal, dan lingkungan dimana kapal itu berada. Kandas merupakan suatu keadaan darurat yang disebabkan karena kandasnya suatu kapal pada dasar perairan baik secara sengaja maupun secara tidak sengaja. Jangkar larat (dragging anchor) adalah suatu keadaan di saat berlabuh jangkar, dimana jangkar kapal larat/menggaruk akibat dari gaya eksternal (arus, angin, cuaca, jenis dasar laut, dan pasang surut) terhadap jangkar yang mempengaruhi kekuatan cengkraman jangkar dan rantai jangkar, serta adanya pengaruh dari faktor internal (jangkar, rantai jangkar, mesin jangkar, draft, sumber daya manusia).

Tanggal 16 Februari 2017 pada saat MV. DK 01 sedang berolah gerak untuk persiapan berlabuh jangkar di anchorage area Pelabuhan Tanjung Intan, Cilacap, kapal tersebut kehilangan jangkar sebelah kiri setelah melaksanakan proses drop anchor dengan cara open brake yang mengakibatkan jangkar kiri tersebut terlepas berikut semua rantai jangkarnya.
Akibatnya MV. DK 01 kehilangan jangkar sebelah kiri dan pelaksanaan berlabuh jangkar terganggu. Metode berlabuh jangkar dengan cara open brake atau juga dapat disebut sebagai letting go ship anchoring method merupakan metode menurunkan jangkar kapal dengan membiarkan jangkar tersebut tergelincir jatuh ke dalam air, berbeda dengan metode walk back dimana jangkar diturunkan dengan hati-hati sampai berapa banyak jumlah segel pada rantai jangkar yang diinginkan.

Dengan mencermati latar belakang dan judul yang sudah ada, peneliti merumuskan rumusan masalah sebagai berikut:

1. Faktor-faktor apakah yang menyebabkan terlepasnya jangkar kiri pada saat berlabuh jangkar di anchorage area Pelabuhan Tanjung Intan Cilacap?

2. Apakah upaya yang perlu dilakukan setelah terlepasnya jangkar kiri pada saat open brake tersebut agar proses berlabuh jangkar dapat dilaksanakan dengan baik?

\section{KAJIAN PUSTAKA}

A. Kajian Pustaka

\section{Pengertian Analisis}

Menurut Komaruddin (2001:53), analisis adalah kegiatan berpikir untuk menguraikan suatu keseluruhan menjadi komponen sehingga dapat mengenal tanda-tanda komponen, hubungannya satu sama lain dan fungsi masing-masing dalam satu keseluruhan yang terpadu. [4] Menurut Kamus Besar Bahasa Indonesia (KBBI, 2002:43), analisis merupakan penguraian suatu pokok dari berbagai bagian atas penelaahan bagian itu sendiri serta hubungan antar bagian untuk memperoleh pengertian yang tepat dan pemahaman arti keseluruhan. [5] Menurut Jimmy L. Goal (2008:73), analisis adalah sebagai penguraian suatu sistem informasi yang utuh ke dalam bagian-bagian komponennya 
dengan maksud untuk mengidentifikasi dan mengevaluasi permasalahan-permasalahan,

kesempatan-kesempatan, hambatan yang terjadi dan kebutuhan yang diharapkan sehingga dapat diusulkan perbaikan-perbaikannya.

\section{Jangkar}

Jangkar merupakan alat labuh yang mempunyai bentuk dan berat khusus yang akan diturunkan ke kedalaman air sampai dengan dasar sehingga pada saat jangkar diturunkan maka kapal sangat terbatas pergerakannya dengan posisi jangkar dan panjang rantai yang diturunkan.

Jenis-jenis jangkar disesuaikan dengan penempatannya pada kapal dan kegunaannya. Kapal-kapal niaga (ocean going ship) dilengkapi dengan 3 tipe jangkar, yaitu:

a. Jangkar Utama atau Jangkar Haluan (Bow Anchor)

Jangkar ini digunakan pada saat berlabuh di daerah labuh (anchorage area). Kedua jangkar ini memiliki berat yang sama dimana beratnya diatur sesuai dengan ketentuan klasifikasi.

b. Jangkar Arus (Steam Anchor)

Jangkar ini digunakan untuk membantu jangkar haluan pada saat berlabuh di daerah yang memiliki arus sangat kuat dan untuk menahan posisi kapal di bagian buritan supaya tetap dalam posisinya.

c. Jangkar Cemat (Kedges Anchor)

Pada sebagian kapal dilengkapi dengan jangkar cemat yang digunakan untuk membebaskan kapal pada saat kapal kandas di dasar yang berpasir.

Jangkar kapal juga dibedakan menjadi beberapa jenis berdasarkan bentuk dan fungsinya, diantaranya:

\section{a. Stockless Anchor}

Jangkar tipe ini bekerja sangat efektif dan memiliki tiang jangkar yang dapat bergerak. Pada saat diturunkan maka bagian lengan akan bergerak ke bawah karena adanya engsel pada bagian mahkota jangkar (crown) dan lengan dapat bergerak dengan sudut $45^{\circ}$. Dengan posisi demikian maka bagian lengan jangkar akan menancap ke dasar laut dan pada saat tertarik oleh rantai jangkar dengan posisi tiang jangkar sejajar dasar laut maka jangkar akan semakin menancap. Untuk melepas dan mengangkat jangkar ini posisi rantai jangkar ditarik tegak dan pada saat tiang jangkar pada posisi tegak maka lengan jangkar akan terungkit sehingga cengkeraman jangkar lepas dan jangkar dapat ditarik ke atas.

Berikut adalah tipe-tipe jangkar yang termasuk ke dalam stockless anchor:

1) Jangkar Hall

Jangkar tipe hall adalah jenis jangkar stockless bow, yaitu stockless anchor yang dipasang pada bagian haluan kapal. Pada umumnya jangkar ini digunakan pada kapal konvensional.

2) Jangkar Spek

Jangkar tipe spek adalah jangkar yang didesain sesuai dengan ukuran tempat penyimpanan jangkar pada kapal. Jangkar jenis ini dulu paling umum digunakan, khususnya pada kapal konvensional.

3) Jangkar Byers

Jangkar tipe byers umumnya digunakan pada kapal konvensional. Berat jangkar ini biasa tersedia dari ukuran $20 \mathrm{~kg}$ sampai dengan 20 ton. 
4) Jangkar Union

Jangkar tipe ini memiliki fungsi dan berat yang sama dengan jangkar byers.

5) Jangkar Baldh

Jangkar ini dibuat pertama kali pada tahun 1901 dan pada tahun 1954 jangkar ini mulai didistribusikan untuk industri offshore.

\section{b. Danforth Stockless Anchor}

Merupakan jenis jangkar yang memiliki daya cengkeram lebih baik dibanding dengan stockless anchor, namun karena adanya tongkat jangkar maka kedua jangkar tidak dapat menancap ke dasar laut. Tiang jangkar tidak dapat langsung masuk ke hawse pipe (ulup jangkar) di kapal. Jangkar yang termasuk ke dalam jangkar jenis ini adalah:

1) Jangkar AC14

Jangkar tipe AC14 adalah jenis jangkar stockless high holding power, artinya dapat dikurangi $25 \%$ dari berat biasanya yang diperlukan untuk jangkar konvensional.

2) Jangkar Stevin

Jangkar stevin merupkan salah satu jangkar yang termasuk ke dalam high holding power anchor karena memiliki kemampuan menahan beban yang tinggi.

3) Jangkar Flipper Delta

Jangkar ini adalah jangkar tipe high holding power anchor. Jangkar ini didesain untuk kebutuhan industri offshore karena memiliki high power capacity.

\section{c. Mushroom Anchor}

Jangkar jenis ini hanya digunakan untuk kapal-kapal yang banyak beroperasi di daerah sungai atau di daerah perairan yang memiliki dasar berlumpur.

Di MV. DK 01 jangkar yang digunakan adalah tipe jangkar stockless anchor dimana jangar tersebut sangat cocok untuk kapal berukuran besar dan sangat efektif karena memiliki tiang jangkar yang dapat bergerak.

3. Bagian-Bagian Jangkar

Berikut adalah gambar bagian-bagian jangkar pada umumnya:

a. Arm (lengan), merupakan bagian dari jangkar yang membentang dari ujung jangkar (crown) akhir, batang jangkar (shank) dan menghubungkan ke telapak jangkar (palm).

b. Band, adalah logam melingkar yang mengamankan dua bagian dari stok kayu secara bersamasama dengan batang jangkar (shank).

c. Bill, adalah akhir dari lengan jangkar (palm).

d. Crown (mahkota), merupakan ujung runcing akhir dari jangkar yang menghubungkan batang jangkar (shank) dengan lengan.

e. Eye (mata), merupakan lubang di akhir batang jangkar (shank) tempat cincin terpasang.

f. Fluke, adalah bentuk sekop bagian dari lengan jangkar ( $\mathrm{arm}$ ) yang digunakan untuk menggali dasar laut dalam mengamankan kapal.

g. Palm, merupakan bagian datar paling atas dari sekop (fluke).

h. Ring, adalah bagian jangkar dimana tali atau rantai melekat dan menghubungkan jangkar ke kapal.

i. Shank, adalah batang tegak dari jangkar.

j. Stock, merupakan lintas bar jangkar yang memungkinkan sekop pada jangkar (fluke) dapat menggali dasar laut. 
4. Perlengkapan Pada Sistem Jangkar Kapal

a. Kabel Baja (Wire Ropes)

Wire rope adalah tali yang dikonstruksikan dari kumpulan jalinan serat-serat baja. Tali baja terdiri dari beberapa serat baja yang dipintal hingga menjadi satu jalinan (strand), kemudian beberapa strand dijalin pada suatu inti (core) sehingga membentuk tali.

b. Tabung Jangkar (Hawse Pipe)

Tabung jangkar merupakan tabung yang dilalui rantai jangkar yang konstruksinya terletak di lambung kapal sebelah kiri dan kanan haluan kapal hingga geladak depan (forecastle deck).

c. Tabung Rantai Jangkar (Chain Pipe)

Tabung rantai jangkar merupakan tabung posisi vertikal/tegak yang dilalui rantai jangkar yang konstruksinya terletak antara dek haluan kapal (forecastle deck) dan bak rantai (chain locker).

d. Bak Rantai Jangkar (Chain Locker)

Bak rantai jangkar adalah tempat penyimpanan rantai jangkar.

e. Mesin Jangkar (Anchor Windlass)

Mesin jangkar merupakan sebuah mesin derek jangkar yang dipasang di kapal untuk keperluan mengangkat dan mengulur jangkar dan rantai jangkar melalui tabung jangkar (hawse pipe)..

f. Chain Stopper

Chain stopper pada umumnya dipasang antara mesin jangkar dengan hawse pipe untuk menahan tarikan rantai dan jangkar saat kapal sedang berlabuh.

\section{Open Brake}

"Let Go: This method is used in over a wide range of vessels including smaller crafts and pleasure yachts to larger vessels with tonnage varying up to $1,00,000$ GT. The principle followed in this method is to let go or let the anchor slip with cable under its own weight from the hawse pipe. The weight on the cable, windlass brake holding power and momentum of the vessel are factors to be controlled by the vessel to ensure the anchor digs in and the cable is subsequently laid to extend backwards. While approaching the anchoring position the speed of the vessel over ground is brought to zero using engines and helm and at the same point anchor along with the cable is allowed to run out under its own weight". "Metode ini digunakan di berbagai macam kapal termasuk kapal kecil dan kapal pesiar sampai ke kapal yang lebih besar dengan tonase bervariasi hingga 1,00,000 GT. Prinsip yang diikuti dalam metode ini adalah melepaskan atau membiarkan jangkar tergelincir dengan kabel di bawah beratnya sendiri dari pipa hawse. Bobot pada kabel, daya pengereman alat pengangkat rem angin dan momentum kapal adalah faktor yang harus dikontrol oleh kapal untuk memastikan jangkar menggali dan kabel kemudian diletakkan untuk memperpanjang dengan bergerak mundur. Sementara mendekati posisi berlabuh jangkar, kecepatan kapal dibawa ke nol menggunakan mesin dan kemudi dan pada titik yang sama jangkar bersama dengan kabel dibiarkan habis di bawah beratnya sendiri.

6. Pengertian Hilangnya Jangkar (Anchor loss)

a. Arti Anchor Loss

Dalam buku Anchoring System and Procedures for Large Tankers OCIMF (1982:1), menyatakan bahwa:

It is because experienced seamen are losing anchors and or cable, 
or experiencing windlass damage when anchoring vessels. This indicates that there is a need to consider the anchoring sytems and the application of techniques to assist Master and Owners in a better understanding of the factors involved. Yang memiliki arti bahwa pelaut yang berpengalaman dalam hal kehilangan jangkar dan rantai jangkar atau mengalami kerusakan mesin jangkar ketika akan berlabuh jangkar. Hal ini menunjukkan bahwa ada kebutuhan untuk mempertimbangkan sistem berlabuh jangkar dan menerapkan teknik untuk membantu Nahkoda dan pemilik kapal dalam pemahaman yang lebih baik tentang faktor-faktor yang terlibat. Hilangnya jangkar dapat menyebabkan banyak kerugian, diantaranya kapal tidak dapat berolah gerak dengan baik, tertundanya proses berlabuh jangkar, dan kerugian finansial dalam pencarian maupun penggantian jangkar yang hilang.

b. Sebab-Sebab Hilangnya Jangkar Hilangnya jangkar dapat disebabkan oleh kurangnya kesadaran crew kapal akan pentingnya proses berlabuh jangkar, kurangnya perawatan terhadap peralatan berlabuh jangkar, serta kondisi lingkungan yang tidak memadai dalam kegiatan berlabuh jangkar.
B. Kerangka Pikir Penelitian

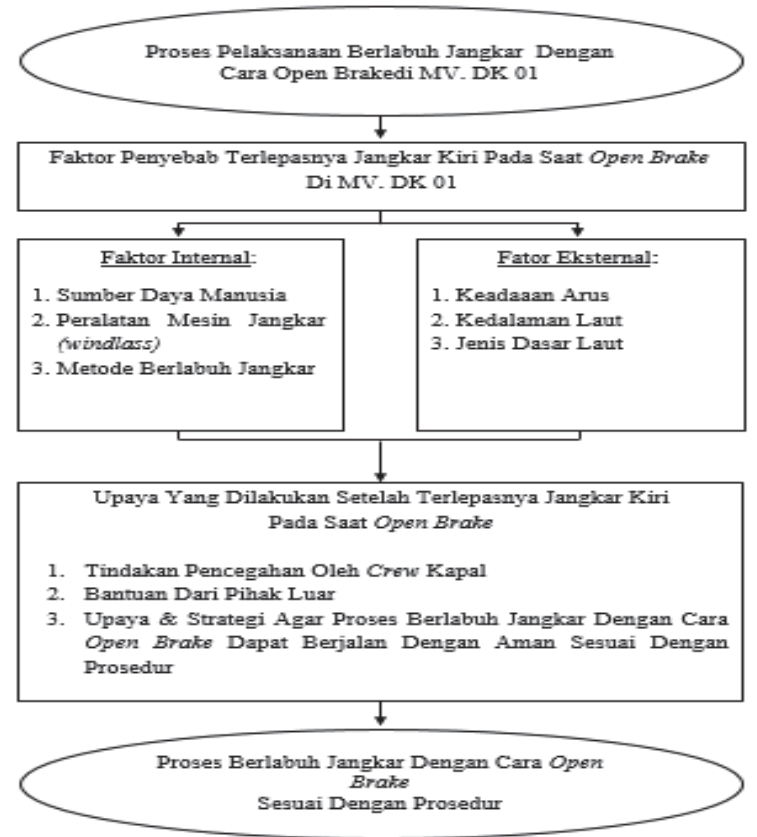

Gambar 1. Kerangka Pikir Penelitian

\section{METODOLOGI}

A. Metode Penelitian

Metode penelitian adalah rangkaian cara terstruktur atau sistematis yang digunakan oleh para peneliti dengan tujuan mendapatkan jawaban yang tepat atas apa yang menjadi pertanyaan pada objek penelitian. Metode yang digunakan oleh penulis dalam penelitian ini adalah metode penelitian deskriptif. Metode ini dapat digunakan untuk menggambarkan, menjelaskan dan menceritakan perincian-perincian data berdasarkan fakta yang ada.

Menurut Sukmadinata (2006), penelitian deksriptif adalah suatu bentuk penelitian yang ditujukan untuk mendeskripsikan fenomena-fenomena yang ada baik fenomena alamiah, ataupun fenomena buatan manusia. Fenomena itu dapat berupa bentuk, aktivitas karakteristik, perubahan, hubungan, kesamaan, dan perbedaan antara fenomena yang satu dengan fenomena yang lain. Penelitian deskriptif berusaha memberikan dengan sistematis dan cermat fakta-fakta aktual dari sifat populasi tertentu dan 
mempunyai kekhususan untuk mencari informasi faktual yang mendetail yang menggambarkan gejala yang ada, mengidentifikasi masalah-masalah aktual yang dihadapi sekarang, mengumpulkan data-data atau informasi untuk disusun kemudian dijelaskan dan dianalisis.

\section{B. Sumber Data}

Sumber data yang penulis pergunakan pada penyusunan penelitian adalah sebagai berikut:

\section{Sumber Data Primer}

Data primer adalah data yang didapat secara langsung dari sumbernya. Data ini dapat berupa opini subyek (orang) secara individu maupun kelompok, hasil observasi terhadap suatu benda (fisik), kejadian atau kegiatan, dan hasil pengujian.

2. Sumber Data Sekunder

Data sekunder bersifat mendukung dan melengkapi data primer. Data sekunder dari penelitian ini diperoleh dari arsip-arsip atau data-data dari buku-buku yang ada di kapal dan perpustakaan kampus Politeknik Ilmu Pelayaran Semarang (PIP) yang mempunyai kaitan dengan objek yang diteliti.

\section{Metode Pengumpulan Data}

Pengumpulan data dimaksudkan untuk memperoleh data-data yang relevan, akurat dan nyata. Masingmasing data memiliki kelebihan dan kekurangan sendiri-sendiri. Oleh karena itu penulis mempergunakan metode pengumpulan data lebih dari satu sehingga data-data yang diperlukan dapat saling melengkapi satu sama lain. Di dalam penelitian ini penulis menggunakan beberapa teknik pengumpulan data, antara lain:

1. Observasi

Observasi diartikan sebagai pengamatan dan pencatatan secara sistematik terhadap gejala yang tampak pada objek penelitian. Penulis mengamati dan melihat kemudian mencatat secara langsung pelaksanaan kerja, aktivitas-aktivitas serta masalah-masalah yang terjadi di atas kapal MV. DK 01 untuk memperoleh gambaran-gambaran yang jelas, otentik dan akurat tentang terlepasnya jangkar kiri pada saat open brake.

2. Wawancara

J. Moleong, MA (2004:135), mendefinisikan bahwa interview sebagai percakapan dengan maksud tertentu. Percakapan itu dilakukan oleh dua pihak yaitu pewawancara yang mengajukan pertanyaan dan yang diwawancarai yang memberikan jawaban atas pertanyaan itu. Dengan metode tersebut penulis mencoba memperoleh data melalui wawancara langsung dengan Perwira kapal dan awak kapal tentang penyebabpenyebab terlepasnya jangkar kiri pada saat open brake di MV. DK 01.

3. Studi Pustaka

Studi pustaka merupakan metode pengumpulan berbagai data dan informasi dengan bantuan bermacammacam sumber yang terdapat di ruang perpustakaan, seperti bukubuku, majalah, dokumen dan lainlain.

D. Teknis Analisis data

Metode analisa data yang digunakan oleh penulis dalam penyampaian masalah adalah metode fishbone untuk menggambarkan dan menguraikan objek yang diteliti dan metode USG (Urgency, Seriousness, Growth) untuk menghasilkan perioritas masalah dalam objek yang diteliti.

1. Metode Fishbone Analysis

Teknik dalam penulisan penelitian ini salah satunya peneliti menggunakan teknik analisa fishbone analysis untuk menggambarkan dan menguraikan objek yang diteliti yang dijabarkan dengan menggunakan fishbone diagram (diagram tulang 
ikan karena bentuknya seperti tulang ikan).

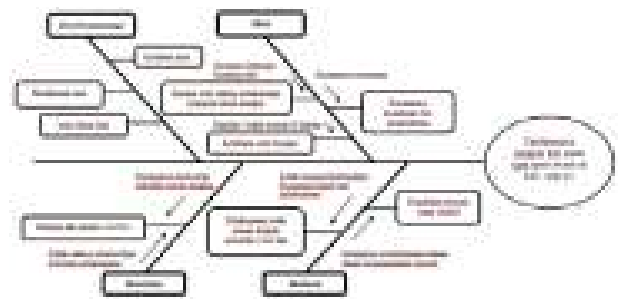

Gambar 2. Fishbone Analysis

2. Metode USG (Urgency, Seriousness, Growth)

Untuk mengetahui prioritas masalah penulis akan menggunakan metode USG (Urgency, Seriousness, Growth). USG adalah salah satu alat untuk menyusun urutan prioritas isu yang harus diselesaikan, caranya dengan menentukan tingkat urgensi, keseriusan dan perkembangan isu. Isu yang dimiliki total skor tertinggi merupakan isu prioritas, untuk lebih jelasnya:

a. Urgency

Seberapa mendesak isu tersebut harus dibahas dikaitkan dengan waktu yang tersedia serta seberapa keras tekan waktu tersebut untuk memecahkan masalah yang menyebabkan isu tersebut.

b. Seriousness

Seberapa serius isu tersebut harus dibahas dikaitkan dengan akibat yang ditimbulkan dengan penundaan pemecahan masalah yang menimbulkan isu tersebut atau akibat yang menimbulkan masalah-masalah lain kalau masalah penyebab isu tidak dapat dipecahkan. Perlu dimengerti bahwa dalam keadaan yang sama, suatu masalah yang lain adalah lebih serius bila dibandingkan dengan suatu masalah yang berdiri sendiri.

c. Growth

Seberapa kemungkinankemungkinan isu tersebut menjadi berkembang dikaitkan dengan kemungkinan masalah penyebab isu akan makin memburuk apabila tidak diatasi akan menimbulkan masalah yang baru dalam jangka panjang.

\section{PEMBAHASAN}

A. Gambaran Umum Objek Yang Diteliti

PT. Karya Sumber Energy Shipping Management adalah salah satu perusahaan pelayaran yang sedang berkembang di Indonesia dan memiliki kapal-kapal bertipe bulk carriers dengan ukuran handysize sampai dengan panamax. Dalam operasinya kapal-kapal di perusahan ini mengangkut muatan batu bara (coal) dan klinker (clincer) dalam bentuk curah. MV. DK 01 merupakan kapal tipe bulk carrier dengan ukuran handy-size bulkers yang memiliki 6 palka sebagai ruang muat dan 3 crane yang digunakan untuk memuat dan membongkar muatan di pelabuhan. Kapal milik PT. KYK LINE PTE LTD ini dikelola oleh perusahaan PT. Karya Sumber Energy (KSE). MV. DK 01 memiliki route pelayaran tetap (liner) dalam operasinya mengangkut muatan batu bara (coal) yang dimuat dari Banjarmasin, Kalimantan Selatan sebagai pelabuhan muat (anchorage area) dan dikirim ke Pelabuhan Tanjung Intan, Cilacap, Jawa Tengah. MV. DK 01 mempunyai 28 orang awak kapal termasuk Nahkoda dan Chief Engineer. Awak kapal terdiri dari 3 orang Officer, 3 orang Engineer, 1 orang Bosun, 3 orang Juru Mudi atau (Quarter Master), 1 orang Mandor (Foreman), 1 orang ahli listrik (Electrician), 3 orang Oiler, 1 orang Koki (Chief Cook) dan 10 orang Cadet (6 deck dan 4 engine). Data kapal secara lengkap (Ship's Particular) dapat dilihat pada lampiran tabel 4.1 Ship's Particular.

Jangkar yang digunakan di MV. DK 01 adalah jangkar bertipe stockless 
anchor dimana jangar tersebut sangat cocok untuk kapal berukuran besar. Jangkar tipe ini sangat efektif karena memiliki tiang jangkar yang dapat bergerak. Rantai jangkar yang digunakan di MV. DK 01 memiliki jumlah total 12 segel dimana panjang setiap segelnya adalah 27,5 meter.

\section{B. Analisa Masalah}

Dalam kegiatan berlabuh jangkar terdapat beberapa tahapan yang harus dilaksanakan agar berjalan dengan baik, yaitu:

1. Persiapan Awal

Berdasarkan

pengamatan, persiapan-persiapan berlabuh jangkar yang harus dilaksanakan oleh crew adalah sebagai berikut:

a. Memilih tempat untuk berlabuh jangkar

Dalam memilih tempat berlabuh jangkar terdapat faktorfaktor yang harus diperhitungkan/dipertimbangkan antara lain adalah:

1) Kedalaman perairan;

2) Kebebasan berputarnya kapal;

3) Kondisi perairan;

4) Komunikasi dengan darat.

b. Menentukan jangkar mana yang akan digunakan dan berapa banyaknya rantai jangkar yang akan dikeluarkan

Nahkoda adalah orang yang menentukan jangkar mana yang akan digunakan pada waktu berlabuh jangkar, apakah jangkar kanan (starboard anchor) atau jangkar kiri (port anchor). Untuk menentukan banyaknya rantai jangkar yang akan dikeluarkan tergantung dari keadaan cuaca, jenis dasar laut, kekuatan arus atau angin, lamanya waktu singgah, dan kedalaman air.

c. Memperhatikan kondisi lingkungan sekitar tempat berlabuh jangkar
Observasi harus dilaksanakan dengan menggunakan visual maupun radar dan alat navigasi lainnya untuk mengamati keadaan lingkungan di sekitar tempat yang akan digunakan untuk berlabuh jangkar agar pelaksanaannya berjalan dengan lancar dan tidak menganggu lingkaran putar kapal terhadap kapal lain.

d. Menentukan metode berlabuh jangkar yang akan digunakan

Metode berlabuh jangkar ditentukan setelah tim anjungan mempertimbangkan faktor-faktor internal, seperti kondisi mesin jangkar (windlass) dan faktorfaktor eksternal seperti keadaan arus, pasang surut, dll.

e. Persiapan crew kapal dalam bertugas dengan menggunakan alat keselamatan diri (personal protective equipment)

Dalam melaksanakan setiap pekerjaan di atas kapal, seluruh crew kapal harus menggunakan alat-alat keselamatan guna melindungi diri mereka sewaktu melaksanakan pekerjaan, termasuk kegiatan berlabuh jangkar. Alatalat yang digunakan seperti wearpack, safety shoes, safety helmet, savety gloves, dll.

f. Komunikasi antara crew yang ada di haluan dan di anjungan dengan cara melakukan pengetesan radio

Seorang Perwira kapal khususnya Chief Mate yang mendapatkan mandat atau berwenang dalam standby depan harus benar-benar membiasakan prosedur dalam pelaporan sesuai dengan SMCP (Standard Marine Communition Phrase). Ketika proses penurunan jangkar, Chief Mate memberikan perintah yang jelas kepada tim haluan sesuai dengan perintah Nahkoda di anjungan dan menginformasikan segara kondisi di haluan termasuk 
posisi dan arah jangkar beserta rantai jangkar saat berlangsungnya proses berlabuh jangkar kepada anjungan.

2. Persiapan Peralatan

a. Mempersiapkan kerja operasi windlass

Mesin jangkar (windlass) merupakan peralatan utama yang digunakan pada saat proses berlabuh jangkar, maka dari itu windlass harus dipersiapkan dengan baik. Karena di MV. DK 01 masih menggunakan sistem pompa hydraulic, maka harus menunggu lubrication oil melakukan sirkulasi di dalam mesin tersebut.

b. Mempersiapkan peralatan windlass

Officer yang bertugas di haluan dan crew kapal harus bekerja sama untuk melepaskan lashing dan bow stopper pada rantai jangkar sebelum dapat dioperasikan, kemudian memeriksa kondisi pipeline mesin windlass tipe hydraulic agar dapat ditindaklanjuti apabila terdapat suatu kebocoran. Selanjutnya adalah memeriksaan rem (brake cleaning) pada saat akan melaksanakan penurunan, brake harus diperiksa terlebih dahulu dan dilakukan uji coba agar brake bisa melakukan pengereman dengan baik.

c. Mempersiapkan anchor day signal

Setelah kapal berlabuh jangkar diwajibkan menaikan sosok benda berbentuk bola hitam di haluan sebagai tanda isyarat visual bahwa kapal sedang berlabuh jangkar.

\section{Pelaksanaan Labuh Jangkar}

Pelaksanaan berlabuh jangkar dapat dilakukan dengan menggunakan dua metode, yaitu metode letting go ship anchoring method (open brake) dan walk back anchoring method. Pelaksanaan proses berlabuh jangkar pada kedua metode ini sangat bergantung kepada kemampuan mesin jangkar dalam mengontrol laju rantai jangkar. Kapal harus dihentikan lajunya sebelum berlabuh jangkar.

MV. DK 01 mengalami suatu keadaan darurat di anchorage area Pelabuhan Tanjung Intan Cilacap, yaitu jangkar kirinya MV. DK 01 terlepas pada saat berlabuh jangkar dengan cara open brake.

> Faktor-faktor yang menyebabkan terlepasnya jangkar kiri pada saat berlabuh jangkar di anchorage area Pelabuhan Tanjung Intan Cilacap:

Faktor-faktor yang menyebabkan terlepasnya jangkar kiri pada saat berlabuh jangkar di anchorage area Pelabuhan Tanjung Intan Cilacap diteliti dengan menggunakan tiga metode, yaitu observasi, wawancara, dan studi pustaka.

a. Bedasarkan observasi

1) Faktor internal

Faktor internal merupakan faktor-faktor yang berasal dari dalam kapal itu sendiri. Faktor tersebut dapat berupa sumber daya manusia, peralatan mesin jangkar (windlass), dan metode berlabuh jangkar yang digunakan.

a) Sumber daya manusia Manusia sebagai operator pelaksanaan kegiatan berlabuh jangkar mempunyai banyak pengaruh terhadap masalah yang sedang dihadapi. Pengetahuan dan kepedulian sumber daya manusia terhadap 
peralatan dalam kegiatan berlabuh jangkar merupakan hal yang harus dibenahi. Apabila pengetahuan crew kapal terhadap pentingnya prosedur berlabuh jangkar kurang, akan dapat menimbulkan kesalahan atau bahkan kegagalan proses berlabuh jangkar.

b) Peralatan mesin jangkar (windlass)

Kondisi peralatan mesin jangkar yang kurang baik dapat mengakibatkan pengoperasian peralatan yang digunakan tidak berjalan dengan lancar dan bahkan mengalami kegagalan. Hal ini disebabkan karena kurangnya perawatan dan pengecekan terhadap peralatan berlabuh jangkar sebelum digunakan. Perawatan rutin bagi setiap peralatan di atas kapal wajib dilakukan guna mengaja kinerja peralatan tersebut agar dapat bekerja dengan baik sesuai dengan prosedur. Setelah dilaksanakan perawatan rutin, perlu adanya pengecekan peralatan setiap akan digunakan agar pada saat dipergunakan peralatan ini dapat bekerja dengan lancar.

c) Metode berlabuh jangkar

Permasalahan yang terjadi ketika proses berlabuh jangkar sedang berlangsung juga disebabkan oleh kesalahan operasional, yaitu pelaksanaan proses berlabuh jangkar yang tidak sesuai dengan prosedur dengan mempertimbangkan segala faktor dan kondisi lingkungan yang cocok terhadap metode berlabuh jangkar yang digunakan, seperti keadaan arus, kedalaman laut, jenis dasar laut, dan kecepatan kapal pada saat proses berlabuh jangkar sedang dilaksanakan. Apabila kecepatan yang digunakan terlalu besar akan membuat jangkar yang diturunkan dengan menggunakan metode letting go ship anchoring method (open brake) di MV. DK 01 tertarik oleh arus dan menyebabkan jangkar terus tergelincir sampai semua rantai jangkar habis dan pada akhirnya rantai jangkar pun terlepas dan keluar dari ulup jangkar.

2) Faktor eksternal

Faktor eksternal merupakan semua faktor penyebab terlepasnya jangkar kiri pada saat berlabuh jangkar di anchorage area Pelabuhan Tanjung Intan Cilacap yang berasal dari luar kapal, seperti:

a) Keadaan arus

Apabila arus terlalu kuat lebih baik menghindari berlabuh jangkar dengan menggunakan metode open brake karena jangkar yang seharusnya bisa menahan kapal tidak akan kuat melawan arus dan dapat menyebabkan jangkar terlepas. 
b) Kedalaman laut Apabila jangkar dilabuhkan tepat pada laut yang dalam, maka jangkar tidak akan sampai ke dasar laut dan hal ini dapat menimbulkan resiko jangkar beserta rantainya tidak akan kuat menahan beban jangkar itu sendiri beserta rantainya karena terlalu banyak diturunkan sehingga dapat menyebabkan jangkar terlepas.

c) Jenis dasar laut

Untuk mencapai kekuatan terbaik dalam kegiatan berlabuh jangkar perlu dipastikan bahwa rantai jangkar dan arah jangkar tetap dalam posisi horizontal di dasar laut dengan kondisi keadaan tanah yang cukup baik. Jenis dasar laut mempengaruhi daya cengkeram jangkar pada saat jangkar menggaruk dasar perairan.

b. Berdasarkan wawancara

Penulis membandingkan
hasil observasi $\begin{array}{r}\text { dengan } \\ \text { bersama }\end{array}$
wawancara
narasumber, yaitu
sebahkoda
penanggung jawab di atas
kapal, Mualim I sebagai
perwira yang bertanggung
jawab di haluan, serta Mualim
II sebagai perwira yang
bertugas di anjungan bersama
dengan Nahkoda.

Upaya yang perlu dilakukan setelah terlepasnya jangkar kiri pada saat open brake agar proses berlabuh jangkar dapat dilaksanakan dengan baik

a. Tindakan pencegahan oleh crew kapal

Tindakan awal yang dilakukan oleh crew kapal khususnya Second Officer setelah jangkar kiri terlepas adalah segera memplotting posisi jatuhnya jangkar kiri tersebut pada peta untuk mencegah hilangnya jangkar kiri yang terlepas itu. Setelah kapal benar-benar berhenti melaju, Nahkoda segera memberikan perintah untuk menurunkan jangkar kanan menggunakan metode walk back secara perlahan menggunakan rem agar tidak terjadi hal yang sama dengan jangkar kiri.

b. Bantuan dari pihak luar

Bantuan yang diberikan dari pihak luar berupa pengiriman tim penyelam untuk mencari jangkar yang hilang. Pencarian jangkar yang terlepas dilaksanakan selama 4 hari dengan menggunakan perahu dan ceruk besi yang dijatuhkan ke laut dan kemudian diseret dengan perahu. Jika dalam pengerukan tersebut terdapat benda yang tersangkut oleh ceruk, maka penyelam akan terjun ke laut untuk memastikan apakah benda yang tersangkut itu adalah jangkar kiri MV. DK 01 yang terlepas.

c. Upaya dan strategi yang dilakukan agar proses berlabuh jangkar dengan cara open brake dapat berjalan dengan aman sesuai dengan prosedur

Upaya yang dilakukan oleh crew kapal agar proses berlabuh jangkar dengan cara open brake dapat berjalan dengan aman adalah dengan mengevaluasi faktor-faktor penyebab terlepasnya jangkar kiri pada saat 
open brake, melaksanakan perawatan rutin dan pengecekan terhadap peralatan berlabuh jangkar sebelum digunakan, serta selalu memperhatikan dan menjalankan prosedur kerja yang sesuai sehingga kejadian terlepasnya jangkar kiri tidak akan terulang kembali.

\section{Pembahasan Masalah}

Penulis menggunakan dua metode/teknik analisis data yang terdiri dari metode fishbone analysis (metode analisa tulang ikan) untuk mencari faktor-faktor penyebab terlepasnya jangkar kiri pada saat berlabuh jangkar di anchorage area Pelabuhan Tanjung Intan Cilacap dan metode Urgent, Seriously, and Growth (USG) sebagai alat untuk memecahkan permasalahan dengan menentukan faktor yang paling berpengaruh terhadap permasalahan yang sedang dihadapi.

Tabel 1. Garis besar isi permasalahan dalam diagram fishbone analysis

\begin{tabular}{|c|c|}
\hline $\begin{array}{c}\text { Faktor yang } \\
\text { diamati }\end{array}$ & Masalah yang terjadi \\
\hline Man (manusia) & $\begin{array}{l}\text { 1. Kurangnya kesadaran crew } \\
\text { kapal } \\
\text { 2. Kurang teliti dalam } \\
\text { pelaksanaan } \\
\text { 3. Kelalaian saat berjaga }\end{array}$ \\
\hline $\begin{array}{l}\text { Method } \\
\text { (metode) }\end{array}$ & $\begin{array}{l}\text { 1. Pelaksanaan metode tidak } \\
\text { efektif } \\
\text { 2. Pelaksanaan tidak sesuai } \\
\text { prosedur yang ada }\end{array}$ \\
\hline $\begin{array}{l}\text { Machine } \\
\text { (mesin) }\end{array}$ & 1. Kinerja dari mesin windlass \\
\hline $\begin{array}{l}\text { Environtment } \\
\text { (lingkungan) }\end{array}$ & $\begin{array}{ll}\text { 1. } & \text { Keadaan laut } \\
\text { 2. } & \text { Kedalaman laut } \\
\text { 3. } & \text { Jenis dasar laut }\end{array}$ \\
\hline
\end{tabular}

Tabel tersebut menunjukan bahwa penyebab terlepasnya jangkar kiri pada saat berlabuh jangkar di anchorage area Pelabuhan Tanjung Intan Cilacap yaitu faktor man (manusia), method (metode), machine (mesin) dan environmental (lingkungan).
1. Man (manusia)

a. Kurangnya kesadaran dan pengetahuan crew kapal tentang kegiatan berlabuh jangkar

Semua crew kapal wajib mengetahui tugas yang harus dilaksanakan dalam kegiatan berlabuh jangkar agar persiapan yang dilaksanakan matang dan sesuai dengan prosedur yang ada. Namun pada kenyataannya, masih terdapat crew di MV. DK 01 yang kurang mengetahui persiapan yang dilakukan sehingga kegiatan berlabuh jangkar tidak maksimal.

b. Kurang teliti dalam pelaksanaan kegiatan berlabuh jangkar

Nahkoda yang tidak memperhatikan kecepatan kapal pada saat memberikan perintah untuk melego jangkar kiri. Kecepatan kapal harus dibuat seminimal mungkin bahkan harus berhenti melaju agar pada saat jangkar diturunkan, rantai jangkar tersebut tidak terbawa oleh kapal dan apabila stopper dan canvas brake tidak kuat menahan laju turunnya rantai jangkar maka akan berakibat rantai jangkar terlepas dari kapal.

c. Kelalaian saat berjaga

Mualim I sebagai penanggungjawab dan komando tim haluan tidak berada di haluan pada saat kejadian. Hal tersebut merupakan sebuah kesalahan. Tugas dan tanggung jawab Mualim I pada saat itu dibebankan kepada Bosun, ABK, dan cadet deck yang berada di haluan, sehingga pelaksanaan proses berlabuh jangkar tidak mendapat perhatian dan prosedur yang baik dari seorang Perwira kapal.

\section{Method (metode)}

Pada saat berlabuh jangkar di anchorage area Pelabuhan Tanjung Intan, Cilacap, MV. DK 01 
menggunakan metode open brake atau letting go ship anchoring method, jangkar diturunkan dan dibiarkan tergelincir tanpa rem sampai jangkar tersebut menyentuh dasar perairan. Tetapi jangkar kiri yang dilego MV. DK 01 terlepas karena pelaksanaannya tidak sesuai dengan prosedur yang ada sehingga tidak efektif.

a. Pemilihan metode yang tidak efektif

Metode yang digunakan dinilai tidak efektif karena pada saat berlangsungnya kegiatan labuh jangkar, tidak memperhatikan faktor yang mendukungnya, seperti dalamnya perairan melebihi syarat kedalaman dimana suatu kapal bisa menggunakan metode open brake (25 meter), keadaan arus dimana kekuatan dan kecepatan arus sangat besar, serta jenis dasar laut yang tidak cocok dengan tipe jangkar di MV. DK 01 (stockless anchor).

b. Pelaksanaan kegiatan berlabuh jangkar tidak sesuai dengan prosedur yang ada

Jangkar kiri dilego pada saat kapal masih dalam kecepatan 4 knots. Hal ini mengakibatkan rantai jangkar tertarik arus yang kuat. Kecepatan kapal yang bergerak melawan arus membuat jangkar tergelincir sangat cepat sehingga canvas brake tidak dapat menahan laju rantai jangkar dan akhirnya jangkar kiri tersebut terlepas.

\section{Machine (mesin)}

Kinerja sebuah mesin ditentukan oleh perawatan dan pengecekan yang dilakukan sebelum mesin tersebut bekerja. Mesin jangkar (windlass) di atas MV. DK 01 jarang mendapatkan perawatan dan jarang dilakukan pengecekan sebelum digunakan. a. Kurangnya perawatan terhadap mesin jangkar (windlass)

Mesin jangkar di atas MV. DK 01 jarang mendapatkan perawatan sehingga kinerjanya pun terpengaruhi oleh masalahmasalah yang ada, seperti kondisi canvas brake yang sudah tipis sehingga kemampuan pengereman mesin jangkar menjadi sangat kurang.

b. Tidak adanya pengecekan sebelum pelaksanaan lego jangkar

Pengecekan terhadap mesin jangkar sebelum mesin tersebut digunakan harus dilaksanakan untuk meyakinkan bahwa mesin jangkar dapat bekerja dengan baik sehingga pada saat pelaksanaan lego jangkar tidak terjadi suatu maslaah (trouble). Pada saat persiapan proses belabuh jangkar, Chief Officer sebagai pemimpin tim haluan tidak memerintahkan crew kapal yang bertugas di haluan untuk melaksanakan pengecekan mesin jangkar terlebih dahulu.

\section{Environtment (lingkungan)}

Kondisi lingungan tidak dapat diatur sedemikian rupa, akan tetapi Nahkoda sebagai pemimpin di atas kapal dapat memprediksi dan mempertimbangkan keadaan lingkungan di sekitar tempat berlabuh jangkar sebelum melaksanakan proses berlabuh jangkar. Faktor lingkungan yang dimaksud antara lain:

\section{a. Keadaan arus}

Semakin besar kekuatan arus dan kecepatan arus maka rantai jangkar yang diturunkan akan semakin cepat tertarik oleh arus. Akibatnya jangkar akan tergelincir lebih cepat dan dapat menyebabkan jangkar terlepas. 
b. Kedalaman laut

Semakin dalam laut maka akan semakin panjang rantai jangkar yang harus diarea. Dalamnya lautan menyebabkan canvas brake tidak dapat menahan beban berat jangkar beserta rantainya sehingga jangkar akan terus terjatuh menuju ke dasar perairan sampai pada jumlah rantai jangkar yang dapat digunakan.

c. Jenis dasar laut

Dasar laut yang landai akan memperkecil kekuatan cengkram sebuah jangkar. Daya cengkram jangkar yang tidak optimal akan mengaibatkan jangkar tidak dapat menggaruk permukaan dan menyebabkan laju kapal tidak dapat tertahan oleh jangkar, sehingga rantai jangkar akan terus tergelincir.

Setelah mengetahui faktor penyebab dari terlepasnya jangkar kiri pada saat berlabuh jangkar di anchorage area Pelabuhan Tanjung Intan Cilacap, selanjutnya dilakukan analisa terhadap permasalahan-permasalahan yang telah digambarkan pada kronologis diagram fishbone menggunakan metode USG (Urgency, Seriousness, Growth) untuk mengetahui tingkat berbahayanya suatu kejadian sebagai berikut:

Masalah A : Kurangnya kesadaran crew kapal akan pentingnya proses berlabuh jangkar, crew kapal kurang teliti dan sering lalai dalam melaksanakan tugas dan tanggungjawabnya pada waktu berdinas jaga.

Masalah B : Pemilihan metode yang kurang efektif dan pelaksanaan proses yang tidak sesuai dengan prosedur yang ada sehingga mengakibatkan proses berlabuh jangkar tidak dapat berjalan dengan baik.

Masalah C : Kurangnya perawatan dan pengecekan terhadap peralatan berlabuh jangkar/mesin jangkar (windlass) sehingga dapat mengakibatkan timbulnya masalah pada saat pengoperasiannya.

Masalah D : Kondisi lingkungan yang tidak mendukung dalam pelaksanaan proses berlabuh jangkar dapat mempersulit jalannya kegiatan tersebut bahkan dapat mengakibatkan suatu kegagalan.

Berdasarkan identifikasi masalah tersebut, selanjutnya masalah tersebut dianalisa dengan menggunakan metode USG sehingga didapatkan prioritas masalah yang harus mendapatkan perhatian secara khusus dalam pelaksanaan proses berlabuh jangkar dengan cara open brake agar dapat berjalan secara efektif.

Tabel 2. Penilaian Prioritas Masalah

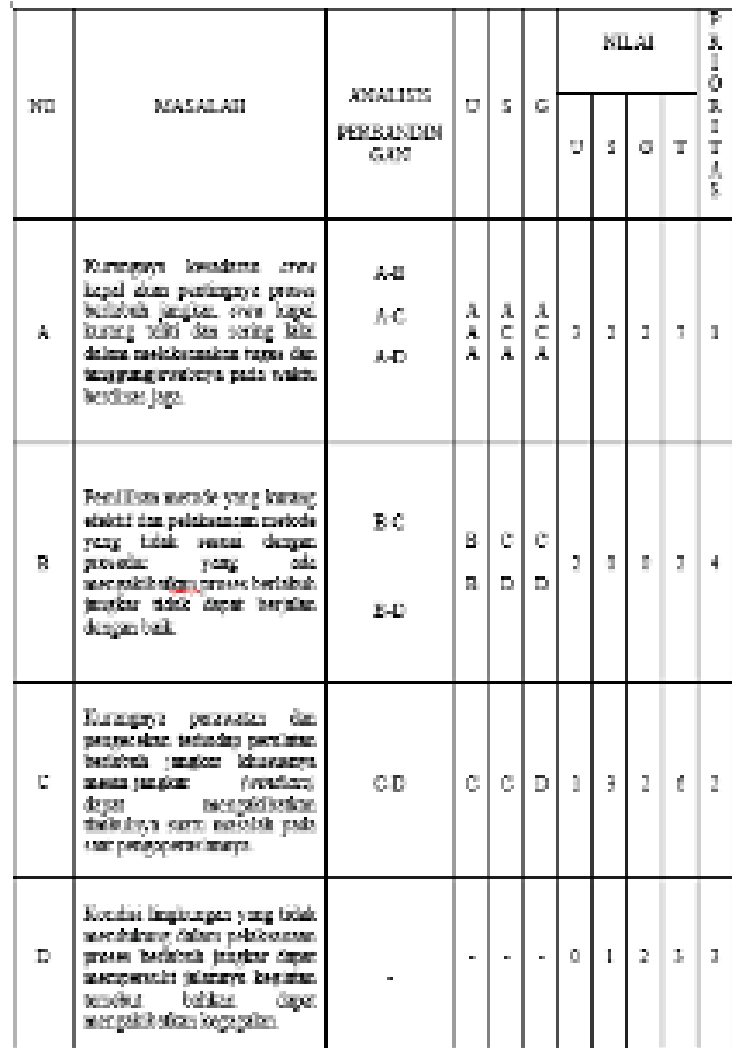


Dari tabel di atas didapatkan skala perbandingan dari tiap-tiap masalah yang dianggap prioritas yang harus segera dipecahkan. Berdasarkan tingkat bahaya suatu kejadian yang pernah dialami yaitu:

Masalah A : Kurangnya kesadaran crew kapal akan pentingnya proses berlabuh jangkar, crew kapal kurang teliti dan sering lalai dalam melaksanakan tugas dan tanggungjawabnya pada waktu berdinas jaga.

Upaya yang dilaksanakan setelah terlepasnya jangkar kiri pada saat open brake di MV. DK 01 agar proses berlabuh jangkar dapat dilaksanakan dengan baik adalah sebagai berikut:

a. Second Officer sebagai perwira yang bertanggungjawab terhadap navigasi di MV. DK 01 langsung memplotting posisi jangkar kiri yang terjatuh untuk menghindari jangkar kiri tersebut hilang.

b. Nahkoda sebagai pemimpin kapal langsung mengambil kebijakan untuk menggunakan jangkar kanan dalam proses labuh jangkar dengan metode yang berbeda, yaitu walk back ship anchoring method dimana jangkar kanan diturunkan dengan hati-hati menggunakan rem untuk menghindari kejadian yang sama.

c. Setelah proses berlabuh jangkar selesai, pihak kapal langsung memberitahukan kejadian tersebut kepada perusahaan dengan menerbitkan laporan hilangnya jangkar kiri. Pihak perusahaan mengirimkan regu penyelam untuk mencari jangkar kiri yang hilang tersebut. Pencarian jangkar dilaksanakan dalam waktu 4 hari dengan menggunakan sebuah ceruk besi yang ditarik oleh sebuah perahu. Pada saat ceruk besi tersebut menggaruk benda pada dasar perairan maka tim penyelam akan terjun ke bawah untuk memastikan bahwa benda tersebut adalah jangkar kiri yang hilang. Setelah ditemukan, rantai jangkar dikaitkan dengan menggunakan tali tross dan ditarik oleh mesin jangkar (windlass). Mandor bersama dengan Chief Engineer masuk ke dalam chain locker dan mengelas rumah keong untuk mengikat ujung rantai jangkar. Jangkar dipasang dengan posisi seperti semula.
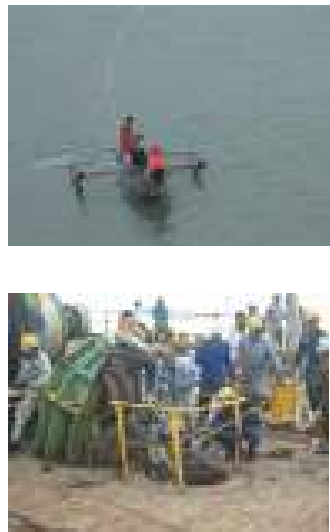

Gambar 3. Proses Pencarian dan Pemasangan Jangkar Kiri MV. DK 01

\section{KESIMPULAN}

\section{A. Kesimpulan}

1. Faktor-faktor yang menyebabkan terlepasnya jangkar kiri pada saat berlabuh jangkar di anchorage area Pelabuhan Tanjung Intan Cilacap, yaitu kurangnya kesadaran crew kapal akan pentingnya proses berlabuh jangkar, pemilihan metode berlabuh jangkar yang kurang efektif dan pelaksanaan proses berlabuh jangkar yang tidak sesuai dengan prosedur yang ada, kurangnya perawatan dan pengecekan terhadap peralatan berlabuh jangkar/mesin jangkar (windlass), kondisi lingkungan yang tidak mendukung dalam pelaksanaan proses berlabuh jangkar. 
2. Upaya yang perlu dilakukan setelah terlepasnya jangkar kiri pada saat open brake agar proses berlabuh jangkar dapat dilaksanakan dengan baik adalah Second Officer sebagai perwira yang bertanggungjawab terhadap navigasi di MV. DK 01 langsung memplotting posisi jangkar kiri yang terjatuh untuk menghindari jangkar kiri tersebut hilang dan Nahkoda sebagai pemimpin kapal langsung mengambil kebijakan untuk menggunakan jangkar kanan dalam proses labuh jangkar dengan metode yang berbeda, yaitu walk back ship anchoring method dimana jangkar kanan diturunkan dengan hati-hati menggunakan rem untuk menghindari kejadian yang sama.

\section{B. Saran}

1. Untuk mengatasi faktor-faktor yang menyebabkan terlepasnya jangkar kiri pada saat berlabuh jangkar di anchorage area Pelabuhan Tanjung Intan Cilacap sebaiknya Nahkoda memberikan pemahaman dan pengawasan tentang tugas dan tanggung jawab masing-masing crew dalam kegiatan labuh jangkar, menentukan metode berlabuh jangkar yang efektif dan pelaksanaan labuh jangkar harus sesuai dengan prosedur agar proses berlabuh jangkar dapat berjalan dengan baik, memerintahkan seluruh crew kapal untuk melaksanakan perawatan rutin dan pengecekan terhadap peralatan berlabuh jangkar tersebut secara berkala serta selalu memperhitungkan kondisi lingkungan terlebih dahulu sebelum melaksanakan proses berlabuh jangkar agar dapat disesuaikan dengan metode labuh jangkar yang akan digunakan.

2. Pada saat Second Officer memplotting posisi jangkar yang terjatuh sebaiknya dilakukan secara cepat untuk mencegah jangkar kiri tersebut hilang dan untuk pelaksanaan labuh jangkar di kemudian hari sebaiknya Nahkoda memperhatikan kembali kecepatan kapal pada saat melaksanakan proses labuh jangkar.

\section{DAFTAR PUSTAKA}

Purwantomo, Agus Hadi. 2018. Mengolah Gerak Kapal. Semarang: Politeknik Ilmu Pelayaran Semarang . 2018. Prosedur Darurat dan SAR. Semarang: Politeknik Ilmu Pelayaran Semarang

Komarudin. 2001. Ensiklopedia Manajemen Edisi IX. Jakarta: Bumi Aksara

Hasan, Alwi, dkk. 2002. Kamus Besar Bahasa Indonesia. Jakarta: Departemen Pendidikan Nasional Balai Pustaka

L. Gaol, Jimmy. 2008. Sistem Informasi Manajemen. Jakarta: PT Gramedia

OCIMF. 1982. Anchoring Systems and Procedures Large Tankers 1st Edition, Witherby \& Co. Ltd for and on behalf of OCIMF

Sukmadinata. 2006. Metode Penelitian Kualitatif. Bandung: Graha Aksara

Moleong, Lexy J. 2004. Metodologi Penelitian Kualitatif. Bandung: Remaja Rosdakarya 